\title{
Response of cotton genotypes to the incidence of Alternaria leaf spot
}

\author{
Edivaldo Cia ${ }^{1,4}$, Milton Geraldo Fuzatto ${ }^{1}$, Julio Isao Kondo ${ }^{1}$, Luiz Henrique Carvalho ${ }^{1}$, Margarida Fumiko Ito ${ }^{2}$, Fábio \\ Luis Ferreira Dias ${ }^{3}$, Paulo Boller Gallo ${ }^{3}$
} ${ }^{1}$ Instituto Agronômico (IAC), Centro de Grãos e Fibras, CEP 13020-902, Campinas-SP; ${ }^{2}$ Instituto Agronômico (IAC), Centro de Fitossanidade;
${ }^{3}$ Agência Paulista de Tecnologia dos Agronegócios, Departamento de Descentralização do Desenvolvimento; ${ }^{4}$ Bolsista do CNPq.
Autor para correspondência: Edivaldo Cia (cia@iac.sp.gov.br)

Data de chegada: 28/08/2015. Aceito para publicação em: 16/08/2016.

$10.1590 / 0100-5405 / 2119$

\begin{abstract}
Cia, E.; Fuzatto, M.G.; Kondo, J.I.; Carvalho, L.H.; Ito, M.F.; Dias, F.L.F.; Gallo, P.B. Response of cotton genotypes to the incidence of Alternaria leaf spot. Summa Phytopathologica, v.42, n.4, p.357-359, 2016.

In field experiments and under natural occurrence of the pathogen, 18 cotton genotypes, comprising cultivars and lineages, were evaluated for their reaction to Alternaria leaf spot caused by Alternaria macrospora Zimm. High genetic diversity of resistance to the pathogen was observed, and four groups of reaction to the disease were detected in the environment where the disease showed greater intensity. Differences in

the phenotypic stability of resistance were also found, and there were stable genotypes, i.e. of expected performance, both in the resistant and in the susceptible material. It must be emphasized that the existence of unstable genotypes of inconsistent performance, according to the intensity of the disease occurrence, can lead to errors with respect to their resistance degree.
\end{abstract}

Keywords: Gossypium hirsutum, Alternaria macrospora, genetic resistance.

\section{RESUMO}

Cia, E.; Fuzatto, M.G.; Kondo, J.I.; Carvalho, L.H.; Ito, M.F.; Dias, F.L.F.; Gallo, P.B. Resposta de genótipos de algodoeiro à incidência de mancha de Alternaria. Summa Phytopathologica, v.42, n.4, p.357-359, 2016.

Em experimentos de campo e sob ocorrência natural do patógeno, 18 genótipos de algodoeiro, compreendendo cultivares e linhagens, foram avaliados quanto à reação à incidência de mancha de alternária, causada por (Alternaria macrospora Zimm). Foi observada alta diversidade genética da resistência ao patógeno, detectando-se a formação de quatro grupos de resposta à doença, em ambiente onde esta ocorreu com maior intensidade. Diferenças quanto à estabilidade fenotípica da resistência também foram verificadas, havendo genótipos estáveis, portanto de desempenho previsível, tanto entre o material resistente quanto no suscetível. É ressaltada, especialmente, a existência de genótipos instáveis, cujo desempenho inconsistente, conforme a intensidade de ocorrência da doença, podem levar a equívocos com respeito ao seu grau de resistência.

Palavras-chave: Gossypium hirsutum, Alternaria macrospora, resistência genética.

Alternaria leaf spot, known and described for more than one century (20), is caused by at least three pathogens: Alternaria macrospora, A. alternata and A. gossypina. The first one is most widespread in the world and has been identified in Brazil $(14,15,17,19)$. Its importance for the cotton crop has been emphasized, especially due to the focus on cultivars of Gossypium barbadense L. causing yield losses of up to $20 \%(11,12,13,20)$ and due to seed transmission (2). However, possible damage caused by this disease to cultivars of Gossypium hirsutum L., the dominant species in Brazilian cotton production, cannot be ruled out, especially when it affects highly susceptible cultivars. Thus, it is important to evaluate the reaction to the disease on available cultivars. In fact, studies carried out both abroad (8) and in Brazil $(1,3,4,5,6,7,9,16,18)$ have shown high genetic diversity for resistance to this pathogen in cotton genotypes. The present study aimed to verify this fact in cotton cultivars and lineages currently available in Brazil.

The study was carried out as three field experiments in the regions of Piracicaba-SP, Mococa-SP and Miguelópolis-SP, respectively, in the 2013/14 growing season. These tests involved 18 cotton genotypes, comprising cultivars and lineages obtained by the major entities that perform breeding programs with this plant in Brazil. In all three trials, one fertilization was carried out on line, using $360 \mathrm{~kg} /$ ha (4: 20: $20+\mathrm{B})$ and cover of $180 \mathrm{~kg} / \mathrm{ha}(20: 00: 20)$. Control of weeds and pests was done as recommended for the cotton crop. There was no significant effect of other diseases. The experiments were designed as randomized blocks with five replicates and plots consisting of one $5 \mathrm{~m}$ line, containing 35 plants after thinning. There was natural incidence of Alternaria and the disease was evaluated when plants were approximately 90 days old by rating the plots from $\mathbf{1}$ to $\mathbf{5}$, according to the following criteria: $\mathbf{1}$ - no plants showing symptoms; $\mathbf{2}$ - up to $10 \%$ plants showing one or two leaves with three lesions at the most; 3 - approximately $30 \%$ plants showing more than three leaves each with around $15 \%$ severity; 4 - 50\% to $80 \%$ plants showing most leaves with around $30 \%$ severity; 5 - more than $80 \%$ plants showing all leaves with more than $30 \%$ severity. Data were transformed into $\sqrt{\mathrm{x}}$ and subjected to analysis of variance and Scott \& Knott test at 5\% probability. In the joint analysis of the experiments, significant genotype $\mathbf{x}$ environment 
interaction was detected. The phenotypic stability of the resistance of genotypes to the pathogen was studied by means of regression analysis between the performance parameters and the indexes representing the average intensity of the disease occurrence at each site, as proposed by Fuzatto et al. (10).

At the three localities, there was a highly significant effect of genotypes, evidencing the expressive genetic diversity among them for disease resistance. The Scott \& Knott means grouping test showed the formation of four groups of reaction to the pathogen in MiguelópolisSP and Mococa-SP. Even in the experiment at Piracicaba-SP, in which the disease occurred to a lower intensity, two distinct groups were found (Table 1).
According to the adopted method, genotypes with regression coefficients not differing significantly from zero in the score $\mathbf{x}$ environment index analysis were considered stable. Two groups of genotypes were well defined concerning the expected performance to the disease. Those that were stable and resistant, attributes that make them safers, included IAC 08-2031, NUOPAL and IMA 09-474 (Table 1), while those that were stable and likely to predict, although with negative performance, included TMG $42 \mathrm{WS}$ and TMG $43 \mathrm{WS}$ as the worst of them. In the intermediate resistance groups, stable genotypes, such as FM 944 GL and FM 975 WS, represent calculated risks, depending on the disease intensity (Table 2). Effectively, even in the absence of cotton yield losses, their use can promote increase in

Table 1. Mean scores in a 1 - 5 scale obtained by cotton genotypes in Alternaria leaf spot evaluation during 2013/14.

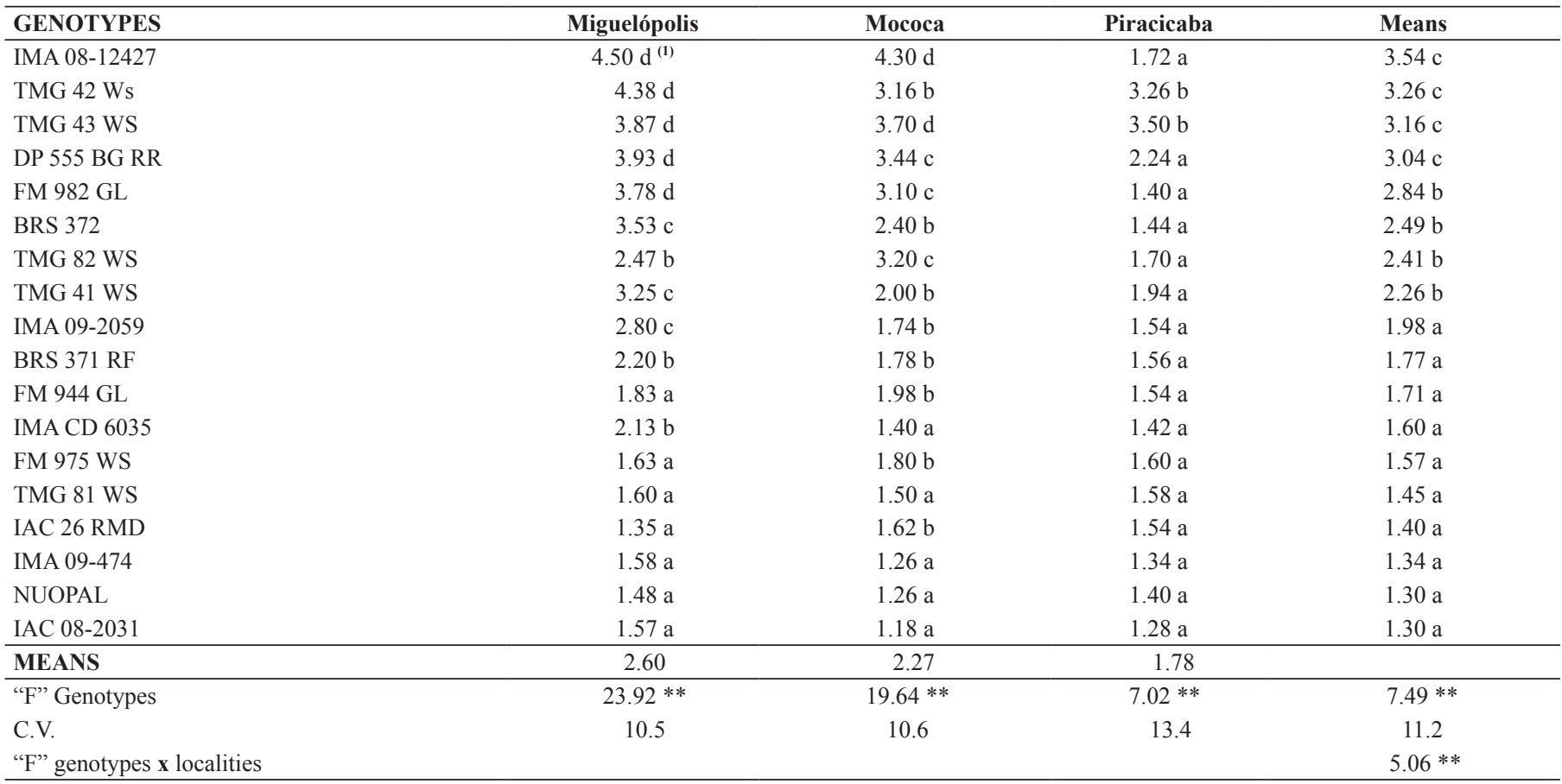

(1) Scott \& Knott test at $5 \%$ probability

Table 2. Parameters and classification obtained by cotton genotypes in the analysis of the phenotypic stability of resistance to Alternaria leaf spot

\begin{tabular}{|c|c|c|c|c|}
\hline Genotypes & $\mathrm{b}$ & " $t "(2)$ & Stability ${ }^{(3)}$ & Resistance $^{(4)}$ \\
\hline IMA 08-12427 & 2.99 & $4.75^{* *}$ & $\mathrm{U}$ & $S$ \\
\hline TMG $43 \mathrm{WS}$ & 0.36 & 0.56 & S & S \\
\hline FM 982 GL & 2.77 & $4.39 * *$ & $\mathrm{U}$ & S \\
\hline BRS 372 & 2.43 & $3.85 * *$ & $\mathrm{U}$ & S \\
\hline TMG $82 \mathrm{WS}$ & 1.07 & 1.69 & S & S \\
\hline IMA 09-2059 & 1.49 & $2.37 *$ & $\mathrm{U}$ & MS \\
\hline BRS $371 \mathrm{RF}$ & 0.81 & 1.29 & S & MR \\
\hline FM 944 GL & 0.43 & 0.68 & S & MR \\
\hline IMA CD 6035 & 0.92 & 1.46 & S & MR \\
\hline FM 975 WS & 0.06 & 0.09 & S & MR \\
\hline TMG $81 \mathrm{WS}$ & 0.01 & 0.02 & S & $\mathrm{R}$ \\
\hline
\end{tabular}

${ }^{(1)}$ Regression coefficients scores $x$ environment indexes. ${ }^{(2)}$ “ $t$ ” test for $b \neq 0 .{ }^{(3)} \mathrm{S}$ (stable) $\mathrm{U}$ (unstable). ${ }^{(4)} \mathrm{R}$ (resistant) MR (moderately resistant) $\mathrm{S}($ susceptible) MS (moderately susceptible) 
the inoculum potential, increasing the disease problem in the future. Finally, it is useful to point out the group of unstable susceptible genotypes, which included IMA 08-12427, FM 982 GL and BRS 372 , as well as the group of moderately susceptible genotypes, such as IMA 09-2059. Their inconsistent performance makes them present the major probability of inducing to error in the classification of the pathogen resistance degree. In fact, if evaluated under less intense incidence of the disease, as in the experiment at Piracicaba-SP, these genotypes may show satisfactory levels of resistance which, however, cannot be confirmed under more severe occurrences of the pathogen, as in the other two trials reported here. What should be emphasized, therefore, is the potential risk of using cultivars with such performance in environments that may favor the development of the disease. It is convenient to point out that yield losses attributable to the disease in question in the present trials were estimated at approximately $12 \%$, when occurring on the most susceptible genotypes.

\section{ACKNOWLEDGEMENTS}

The study was financially supported by "Fundação de Amparo à Pesquisa do Estado de São Paulo" (FAPESP) and "Instituto Matogrossense do Algodão" (IMA-mt)

\section{REFERENCES}

1. Araújo, A.E.; Suassuna, N.D.; Farias, F.J.C.; Freire, E.C. Avaliação da resistência de linhagens de algodoeiro às manchas de Alternaria, Stemphylium e Ramularia. In: Congresso Brasileiro do Algodão, 4., 2003. Goiânia-GO, Anais. Campina Grande-PB, EMBRAPA/CNPA. 2003. CD ROM.

2. Arias, S.M.S.; Arias, E.R.A.; Loeff, F.; Henrichsen, I.; Liell, R.M. Microflora fúngica associada à sementes de algodão oriundas da região de Chapadão do Sul, MS. Safra 1999/2000. In: Congresso Brasileiro do Algodão, 3., 2001. Campo Grande-MS. Resumos. Campina Grande-PB, EMBRAPA/ CNPA. 2001. p. 574-576.

3. Chiavegato, E.J.; Gridi-Papp, I.L.; Fuzatto, M.G.; Carvalho, L.H.; Cia, E.; Kondo, J.I.; Gondim, R.M.A. Comportamento agronômico das variedades estudadas no ensaio internacional de algodoeiro herbáceo. In: Reunião Nacional do Algodão, 7. 1993 Cuiabá-MT. Resumos. Campina Grande-PB. EMBRAPA/CNPA. 1993. p. 29.

4. Cia, E.; Fuzatto, M.G.; Chiavegato, E.J.; Gridi-Papp, I.L.; Sabino, J.C. Comportamento de variedades de algodoeiro herbáceo em face a ocorrência da mancha de Alternaria. In: Reunião Nacional do Algodão, 5. 1988. Campina Grande-PB. Resumos. Campina Grande-PB, EMBRAPA/ CNPA. 1988. p.26.

5. Cia, E.; Salgado, C.L. Doenças do algodoeiro In: Kimati, H.; Amorim, L.; Rezende, J.A.M; Bergamin Filho, A.; Camargo, L.E.A. Manual de Fitopatologia. Doenças das Plantas cultivadas. $4^{\text {a }}$.Ed. Editora Agronômica Ceres Ltda. São Paulo. p 41-52, 2005.

6. Cia, E.; Fuzatto, M.G.; Kondo, J.I.; Galbieri, R.; Luders, R.R.; Almeida, W.P.; Oliveira, A.B.; Krzyzanowsky, A.A.; Lebedenco, A.; Martins, A.L.M.; Morello, C.L.; Pereira, J.D.; Mesquita Neto, D.R.; Bolonhezi, D.; Foltran,
D.E.; Chiavegato, E.J.; Machado, F.E.; Furlani Junior, E.; Takizawa, E.K.; Dias, F.L.F.; Farias, F.J.C.; Kasai, F.S.; Ohl, G.A.; Cunha, H.F.; Belot, J.L.; Cavichioli, J.C.; Carvalho, L.H.; Beriam, L.O.S., Oliveira, M.A.C.; Lanza, M.A.; Ito, M.A.; Pereira, M.; Michelotto, M.D.; Ito, M.F.; Pedrosa, M.B.; Suassuna, N.D.; Vilela, P.A.; Gallo, P.B.; Reco, P.C.; Aguiar, P.H.; Mattos, R.E.M.F.; Freitas, R.S. Desempenho de cultivares e linhagens de algodoeiro em face da ocorrência de doenças e nematoides. Resultados de 2007/08 e 2008/09. Boletim Científico do Instituto Mato-grossense do Algodão 2. Cuiabá-MT. 2011. P.27-28.

7. Cia, E.; Fuzatto, M.G.; Almeida, W.P.; Kondo, J.I.; Ito, M.F.; Dias, F.L.F. Reação de genótipos de algodoeiro a mancha-de-alternária. Summa Phytopathologica, Botucatu, 40(1):81-83, 2014.

8. Cotti, P.J. Evaluation of cotton cultivar suscetibility to Alternaria leaf spot. Plant Disease, Saint Paul, 71:1082-1084, 1987.

9. Freire, E.C.; Farias, F.J.C.; Aguiar, P.H.; Araújo, A.E. Comportamento de novas cultivares e linhagens com relação a doenças no centro-oeste. Safra 1998/99. In: Congresso Brasileiro do Algodão, 2. 1999. Ribeirão Preto-SP. Anais. Campina Grande-PB. EMBRAPA/CNPA. 1999..p. 454-457.

10. Fuzatto, M.G.; Cia E.; Kondo J.I. Estabilidade fenotípica, um complemento relevante na avaliação e classificação genotípica de algodoeiro para resistência a doenças. Summa Phytopathologica, Botucatu, 39(2):117-121, 2013.

11. Hillocks RJ (1992) Fungal diseases of the leaf. In: Hillocks, R.J. Cotton diseases. Ed. C.A.B. Wallingford, International p. 191-192.

12. Laidou, R.J.; Koulakiotu, E.K.; Thanassoulopoulus, C.C. First reporter on stem canker caused by Alternaria alternate on cotton. Plant Disease, Saint Paulo, 84(1): 103, 2000.

13. Lima, E.F.; Carvalho, J.M.F.C.; Batista, F.A.Z.; Santos, J.W. Avaliação do nível de resistência a Alternaria sp. Campina Grande, EMBRAPA/CNPA. Comunicado Técnico 40. 4p, 1995.

14. Lima, E.F.; Batista, F.A.Z.; Vieira, R.M. Principais doenças do algodoeiro e seu controle. In: Beltrão, N.E.M. (Ed.). O agronegócio do algodão no Brasil. 1'. Ed. Brasília-DF, EMBRAPA. 1999. p.715-752.

15. Metha, Y.R.; Cassetari Neto, D.; Cia, E.; Pizzinatto, M.A.; Teixeira, E.A.; Cunha, H.C. (2004) Variabilidade genética entre isolados de Alternaria macrospora do algodoeiro. Summa Phytopathologica, Botucatu, 30(4):480-487, 2004.

16. Mehta, R.; Teixeira, E.A.; Cunha, H.; Erivaldo, J.; Ruano, O. Resposta diferencial das cultivares de algodoeiro a Alternaria macrospora. Summa Phytopathologica, Botucatu, 32(2):186-187, 2006.

17. Pizzinatto, M.A.; CIA, E.; Parisi, J.J.D.; Medina, P.F.; Fuzatto, M.G. Associação de Alternaria macrospora e A. alternata em sementes do algodoeiro e sua ação patogênica. Summa Phytopathologica, Botucatu, 31(4):311-318, 2005

18. Suassuna, N.D.; Morello, C.L.; Freire, E.C.; Araújo, A.E.; Santos, J.W. Andrade, F.P.; Fernandez Junior, I.; Assunção, J.H.; Bezerra, W. Resistência de cultivares de algodoeiro às manchas de Ramularia, Alternária, mancha angular e "doença azul" no estado de Goiás. . In: Congresso Brasileiro do Algodão, 4. 2003. Goiânia-GO. Campina Grande-PB. EMBRAPA/ CNPA.2003. CD ROM.

19. Suassuna, N.D.; Coutinho, W.M.; Asmus, G.Ll; Inomoto, M.M.; Chitarra, L.G. Manejo de doenças do algodoeiro. In.: Beltrão, N.E.M; Azevedo, D.M.P. editores técnicos. O Agronegócio do Algodão no Brasil. $2^{\mathrm{a}}$. Ed. Brasília-DF. Embrapa Informação Tecnológica. 2008. p.983-1032, 2008.

20.Watkins, G.M. Compendium of cotton diseases. St. Paull, Minnesota. The American Phytopathology Society. Cotton Disease Council. Minnesota. 87p, 1981. 